\title{
RUSSIA'S LABOR MARKET: THE SPECIFICITIES OF ITS ADAPTATION TO THE CURRENT CRISIS ${ }^{1}$

\author{
V.Lyashok
}

As in all of Russia's earlier economic crises, wage flexibility has become the main mechanism of the labor market's adaptation to the current crisis. As a result of the high rate of inflation observed in late 2014 - early 2015, real wages dropped by 9.5\%, although nominal wages remained unchanged. The considerable reduction in labor costs made it possible for employers to abstain from cutting jobs, due to which the rise in the unemployment rate was utterly insignificant.

Like in earlier cases of economic recession, the main factor of the labor market's adjustment to adverse economic conditions was wage dynamics. The sharp rise in the rate of inflation in late 2014 - early 2015 meant that employers could significantly reduce labor costs by simply not increasing nominal wages. According to preliminary estimates released by Russian Federal State Statistics Service (Rosstat), in 2015, the average nominal monthly charged wage amounted to $\mathrm{Rb} 33,925$, which represented a $4.6 \%$ rise on 2014. Moreover, its growth in some types of economic activity was even more modest than that: by only $0.2 \%$ in financial activities, and by $1.8 \%$ in construction, while in public administration, military security provision, and social insurance nominal wages declined even lower - by $0.9 \%$. The largest growth in wages was observed in agriculture and the fishing industry - the two sectors least affected by the crisis. The insignificant rise in nominal wages, which took place against the backdrop of high inflation, resulted in real median wages sinking by $9.5 \%$ in 2015 . Thus, they suffered a much more severe decline than that observed during the previous crisis, when real wages had dropped by only $3.5 \%$, although Russia's GDP had plummeted by $7.8 \%$.

The month-on-month dynamics of nominal wages indicate that that their growth rate gradually declined over the period 2014-2015. By the end of that period, their growth had practically ended (Fig. 1). Thus, in December 2015 , nominal wages were only $1.6 \%$ higher than in December 2014.

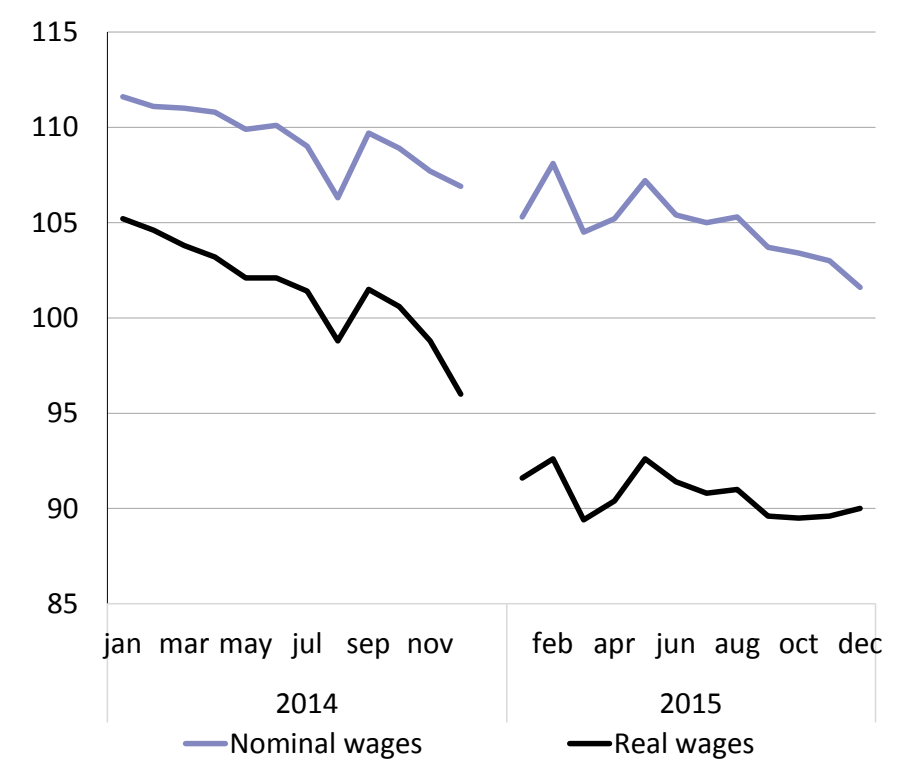

Source: Informatsiia o sotsial'no-ekonomicheskom polozhenii Rossii, dekabr' $2015 \mathrm{~g}$ [Data on the social and economic situation in Russia, December 2015], Rosstat.

Fig. 1. The Dynamics of Nominal and Real Wages, As a Percentage of the Corresponding Month of the Previous Year

1 This paper was originally published in Online Monitoring of Russia's Economic Outlook No.2(20). 
The drop in real wages caused by rising inflation made it almost unnecessary for employers to resort to other mechanisms of reducing labor costs.

According to preliminary estimates released by Rosstat, in 2015, the number of individuals involved in economic activities increased by 1.2 million (without taking into account the Republic of Crimea and the city of Sevastopol), while the level of economic activity grew by 0.3 p.p. Despite the rise in the size of Russia's labor force, employment-related indicators remained unchanged relative to 2014, while the unemployment rate based on the ILO definition increased only by 0.4 p.p. The increase in the number of individuals involved in economic activities was primarily due to the growth of its number in urban areas. The registered unemployment rate also went up only slightly on 2014.

Thus, the economic recession has not as yet resulted in any noteworthy increase in the unemployment rate. This feature distinguishes the current situation from the previous economic crisis of 2007-2009, when the unemployment rate had grown by 2.7 p.p.

The share of part-time workers (working less than 30 hours per week) and temporarily absent workers went up only slightly - from $8.3 \%$ over the first three quarters of 2014 to $8.8 \%$ over the same period of 2015.

Frequently, the move into the informal sector is one of the ways to escape unemployment. Therefore,

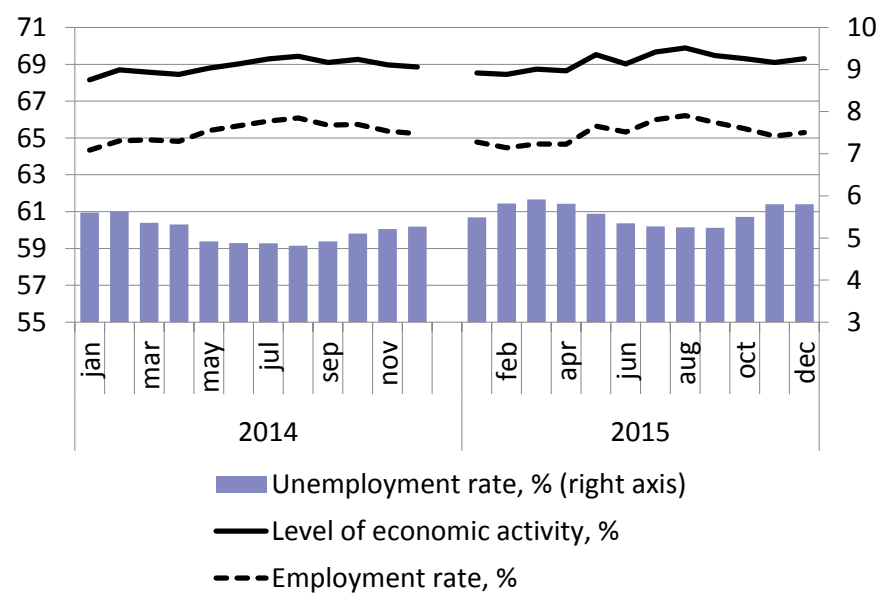

Sources: Sotsial'no-ekonomicheskoe polozhenie Rossii, dekabr' 1914 - noiabr' $2015 \mathrm{~g}$. [The social and economic situation in Russia, December 2014 - November 2015]. Rosstat; Zaniatost' $b$ bezrabotitsa $v$ Rossiiskoi Federatsii v dekabre 2015 g. (po itogam obsledovanii naseleniia po problemam zaniatosti), operativnaia informatsiia [Employment and unemployment in the Russian Federation in December 2015 (labor force survey data), operational data], Rosstat.

Fig. 2. The Rates of Economic Activity, Employment and Unemployment in 2014 and 2015 (Without the Crimean Federal Okrug)

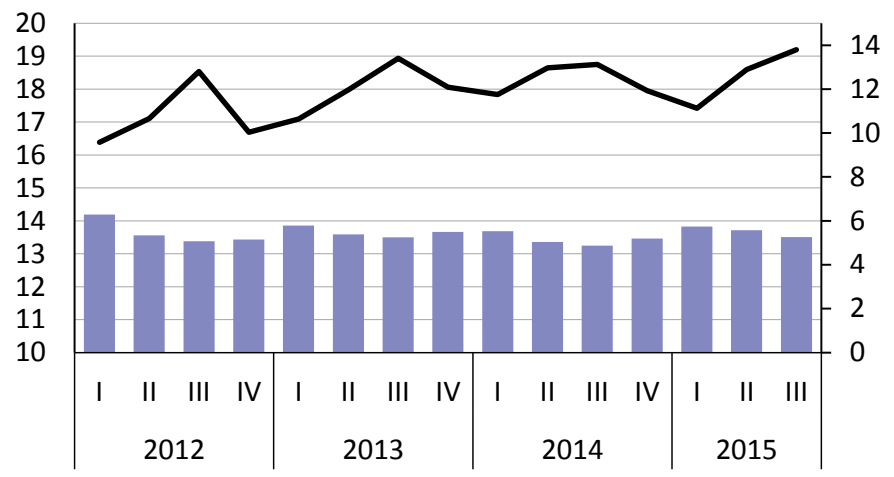

Unemployment rate (right-hand side axis)

- Share of persons employed exclusively in informal sector (lefthand side axis)

Source: Obsledovanie naseleniia po problemam zaniatosti [Labor force survey, Q3 2015], Rosstat.

Fig. 3. The Unemployment Rate and the Share of Persons Employed Exclusively in the Informal Sector the dynamics of these indicators usually show countervailing trends (Fig. 3). Rosstat data for Q1-3 2015 indicate that the number of persons employed exclusively in the informal sector has remained at the level of 2014 (however, with a slight upward trend which emerged in Q3).

Delays in the payment of employees' wages as one of the ways to cut labor costs, which were so widespread in the 1990s, has become a rather rare phe- 
nomenon nowadays. Although the number of wage arrears cases as of the end of 2015 was 1.5 times higher than as of the end of 2014, the number of workers affected by such policies amounted to only 90 thousand (or $0.12 \%$ of all employed persons). The rise in the number of wage arrears cases was caused, among other things, by the bankruptcy of Transaero Airlines, which accounted for $19 \%$ of the total wage arrears accumulated by Russia's medium-sized and large companies as of the end of $2015^{1}$.

Thus, the current situation on the labor market resembles in many respects the situation in the other sectors of Russia's economy: a decline in many indicators, but no catastrophic drops. The only exception is the ongoing decline in real wages caused by rising inflation. This situation can be explained by fact of the present crisis being so slow-motion and lengthy.

1 Vedomosti [The Record], Dolgi Transaero po zarplatam isportili federal'nuiu statistiku [Transaero's wage arrears have spoiled federal statistics], See http://www.vedomosti.ru/business/articles/2016/01/29/625974-dolgi-transaero-zarplatam-isportili-federalnuyu-statistiku 